\title{
The Trauma of Betrayal in The Good Soldier
}

\section{The Good Soldier'da Aldatılma Travması \\ Merve SARIKAYA ŞEN*}

\begin{abstract}
Analysing literary texts by using trauma theory provides remarkable insight into how a character goes through different stages of trauma from acting out towards healing. This paper proposes a reading of Ford Madox Ford's The Good Soldier (1915) as a trauma narrative with its different aspects of a traumatically affected character, John Dowell. The paper first looks at how the confused narrator John Dowell acts out his trauma of betrayal in the forms of repression, amnesia, deferred action, and affective numbing. It then focuses on how he tries to deal with his traumatic memories of adultery by transforming them into a comprehensive narrative but fails to do so. This paper suggests that although trauma theory has its roots in psychoanalysis, it provides the possibility of reading literary texts such as The Good Soldier from a different perspective. In the novel, John Dowell is a telling example of a traumatically affected character incessantly performing his traumatic memories.
\end{abstract}

Keywords: Ford, The Good Soldier, trauma, betrayal, repression, amnesia, nachträglichkeit, affective numbing, working through trauma.

\section{$\ddot{O} z$}

Travma teorisini kullanarak edebi metinleri incelemek, bir roman karakterinin travmanın ortaya koyulmasından iyileşmesine kadar olan farklı süreçlerinden geçişini anlama olanağı sağlar. Bu çalışma Ford Madox Ford'un The Good Soldier (1915) adlı romanında John Dowell'i travmatize olmuş bir karakter olarak ele alarak, romanın bir travma anlatısı olduğunu öne sunar. Bu doğrultuda, kafası karışmış olan John Dowell'in aldatılma travmasını bastırma, amnezi, gecikmiş etki ve afektif hissizleşme gibi travma belirtileriyle sergileyişini inceler. Sonrasında ise Dowell'in travmatik aldatılma anılarını detaylı bir anlatıya çevirerek onlarla başetmeye çalışmasına fakat travmasına hapsoluşuna odaklanır. Böylece, bu çalışma travma teorisinin psikoloji alanında ortaya çıkmasına rağmen, The Good Soldier gibi edebi metinleri farklı bir açıdan değerlendirme imkanı sunduğunu önerir. Buna bağlı olarak da John Dowell travmatik anılarıyla boğuşan bir karakter örneği olarak karşımıza çıkar.

Anahtar Kelimeler: Ford, The Good Soldier, travma, aldatma, bastırma, amnezi, gecikmiş etki, afektif hissizleşme, travmayla başetme.

Patricia Moran argues that modernist narrative with an "emphasis on interiority, memory, psychological verisimilitude, and personal isolation, and its development of fragmented, non-linear plots, provides an ideal medium for the transcription of traumatic experience" (2007, p.3). In this context, as a modernist narrative, Ford Madox Ford's The Good Soldier (1915) with its non-chronological plot and emphasis on the psychological entanglements of the narrating protagonist John Dowell traumatised by his wife Florence's suicide and her adulterous personality deserves great attention. The novel has been analysed from various perspectives. Rebecca West, for example, finds The Good Soldier witty with "all sorts of acute discoveries about human nature" and with "a force of passion which so sustains the story in its flight that never once does it appear as the work of a man's invention" (1915/1997, p.45), while Theodore Dreiser contends that it is a tragic story in "the best sense that the Greeks knew tragedy" but fails to achieve a high result because its characters cannot "stand forth unmistakeable in their moods and characteristics" $(1915 / 1997$, p.50). Traditional criticism focused on "the novel's unique importance as an anatomy of the world of English society just before the first world war" (Bort, 1967, p.195), while more recent criticism has delved into "the historical processes we define as postmodern [that] erupt through precisely the long list of things that Dowell claims to know nothing about yet is haunted by" (Robertson, 1993, p.173). From a different yet related perspective, Hakan Y1lmaz analyses the novel in light of the phenomenological conceptualisation of the self and argues that "Dowell's selfconception and identity which he desperately needs to maintain for self-justification are fundamentally marked by the intersubjective relations he forges with others in the course of the novel" (2017, p.162). Although these views cast significant light on the novel, they do not

\footnotetext{
* Dr. Öğr. Üy. Başkent Üniversitesi, Amerikan Kültürü ve Edebiyatı Bölümü, sarikaya @baskent.edu.tr.
}

Sarıkaya Şen, M, (2018). The Trauma of Betrayal in The Good Soldier, Gaziantep University Journal of Social Sciences, 17 (2), 479-486, Submission Date: 27-11-2017, Acceptance Date: 21-03-2018.

Araştırma Makalesi. 
provide much information about John Dowell's traumatic experiences which bring about confusions and psychological problems. The aim of this paper is to explore how the baffled narrator John Dowell goes through different symptoms of trauma and tries to transform his traumatic experiences into a comprehensive narrative but fails to do so.

Divided into four parts, The Good Soldier presents the story of the disintegrating relations between John and Florence Dowell, an American couple, and Edward and Leonora Ashburnham, a British gentry's couple, and the mental breakdown of Leonora's ward, Nancy Rufford. The couples meet at Nauheim spas and become friends. During their nine year friendship, Florence and Edward have an affair unbeknownst to John. Leonora is aware of their affair and tries to inform John about it but he is too naïve to understand what she says when he hears it for the first time. The novel gradually progresses towards a certain disaster of the couples' friendship. For most of the nine years, Dowell thinks they have a decent and respectable life. He believes that Florence is suffering from a real heart ailment which poses a limit to their sexual contact, restricts her travel, and forces her to stay in her room alone. Yet, he soon realizes that there is no problem with his wife's heart but she has been lying to him. When he learns the fact that she has an extra-marital affair first with Jimmy, a young man of the lower class, and later with Edward, he is utterly shocked. As this description suggests, Florence is an adulterous person. Besides, we learn about her jealousy on the night she sees Edward alone in the park with Nancy. On the same night, she sees that John is informed by an Englishman called Mr. Bagshawe about her affair with Jimmy. Seeing Edward alone with Nancy and Mr. Bagshawe talking to John drags Florence to commit suicide. In line with this, John is traumatised not only by his wife's adulterous personality but also her suicide.

Using trauma theory in understanding John Dowell's predicament provides invaluable insight into The Good Soldier. Roger Luckhurst explains that the word trauma "derives from the Greek word meaning wound" (2). There is a resurgence of interest in trauma studies in the last thirty years but the origins of the word go back to the studies of Sigmund Freud and Josef Breuer. According to Freud and Breuer, what mainly qualifies trauma is its repression. In one of their most cited essays, "On the Psychical Mechanism of Hysterical Phenomena", they underline the fact that traumatic neurosis is based on psychological factors:

the operative cause of the illness is not the trifling physical injury but the affect of fright - the psychical trauma. In an analogous manner, our investigations reveal, for many, if not for most, hysterical symptoms, precipitating causes which can only be described as psychical traumas. Any experience which calls up distressing affects - such as those of fright, anxiety, shame or physical pain - may operate as a trauma of this kind. (1893/2001, pp. 5-6)

They go on to argue that such distressing affects are "absent from the patients' memory when they are in a normal psychic state" $(1893 / 2001$, p.7) because they are repressed in the unconscious. Similarly, Cathy Caruth states that because of "the inability fully to witness the event as it occurs, or the ability to witness the event fully only at the cost of witnessing oneself" (1995, p.7, emphasis in the original), traumatic symptoms are repressed by the subject.

Such repressed symptoms tend to be followed by an amnesia for the traumatic past, as conceptualised by Jean-Martin Charcot (1991/2014, p.376). Drawing on his arguments, Caruth reintroduces amnesia for the traumatic past and argues that the images of traumatic experiences are "largely inaccessible to conscious recall and control" and "the vivid and precise return of the event appears ... to be accompanied by an amnesia for the past" (1995, pp.151-152, emphasis in the original). What she suggests is that it may be difficult for the traumatized subject to recall the traumatic event in precise details because it is incomprehensible for consciousness. 
In line with this, trauma is mainly associated with the revival of repressed memories, which Freud describes as Nachträglichkeit or the reactivation of deferred traumatic events. $\mathrm{He}$ argues that "a memory is repressed which has only become a trauma by deferred action" (1895/1950) p.356, emphasis in the original). Drawing on his arguments, Ruth Leys notes that what constitutes trauma is the dialectic between two events; the traumatising event is reactivated by a second traumatic event, as a result of which the past traumatic event is available in an incomplete or fragmented form (2000, p.20). From a related perspective, Susana Onega and Jean-Michel Ganteau argue that "it is only after this second event that the symptoms of the trauma are expressed in the form of nightmares or flashbacks" and the traumatic event is "experienced again with full force but perceived as incomprehensible and belonging in the present" (2011, p.11). Therefore, Nachträglichkeit results in "obliterating the distinction between past and present and disrupting the linear model of temporality" (Onega and Ganteau 2011, p.10) when considering traumatic memories.

In Moses and Monotheism (1939), Freud explains the temporal gap between the first and the second traumatic event as follows:

It may happen that someone gets away, apparently unharmed, from the spot where he has suffered a shocking accident, for instance a train collision. In the course of the following weeks, however, he develops a series of grave psychical and motor symptoms, which can be ascribed only to his shock or whatever else happened at the time of the accident. (1939, p.109).

Hence, we can say that the traumatised subject does not respond to the traumatic affect in the present but responds later. To put it differently, instead of recalling the traumatic event, the traumatised subject relives it in different forms in the following periods. In "Remembering, Repeating, and Working Through", Freud argues that the traumatized subject

does not remember anything of what he has forgotten and repressed, but acts it out. He produces it not as a memory but as an action; he repeats it, without, of course, knowing that he is repeating it ... he cannot escape from this compulsion to repeat; and in the end we understand that this is his way of remembering. (1914/2001, p.150, emphasis in the original).

Therefore, it might be argued that the traumatised subject represses the essential part of the traumatic event but acts it out unconsciously in the form of actions.

There are various ways of acting out one's traumatic past. As Caruth states, the traumatized subject acts out traumatic events through "repeated, intrusive hallucinations, dreams, thoughts, or behaviours stemming from the event, along with numbing that may have begun during or after the experience, and possibly also increased arousal to (and avoidance of) stimuli recalling the event" (1995, p.4). Accordingly, the traumatized subject is "possessed" by such traumatic memories (Caruth, 1995, p.4). Hence, traumatic experiences act like revenants for traumatised subjects; although they are repressed in the unconscious, they make their presence felt like a ghostly being.

Ford Madox Ford's The Good Soldier is a telling example of the representation of traumatic experiences. What Ford does is to account for the predicament of John Dowell traumatised by betrayals and suicides. As narrated by Dowell, when they visit the ancient city of $\mathrm{M}-$, in the first or second year of their friendship, he starts to see the intimacy between Edward and Florence. While talking about the place they are visiting, Florence lays one finger on Edward's wrist, which evokes eerie feelings in Dowell: "I was aware of something treacherous, something frightful, something evil in the day ... it was as if my heart had missed a beat" (Ford, 1915/1990, p.53). Leonora, too, is aware of the relationship between Edward and Florence and tries to warn John of their betrayal in vain:

I can't stand this ... Don't you see what's going on? ... Don't you see that that's the cause of the whole miserable affair; of the whole sorrow of the world? And of the eternal damnation of you and me and them (Ford, 1915/1990, p.54). 
Dowell, however, cannot believe his ears and does not know how to react: "I don't remember how she went on; I was too frightened; I was too amazed. I think I was thinking of running to fetch assistance - a doctor, perhaps, or Captain Ashburnham" (Ford, 1915/1990, pp.54-55). Rather than trying to grapple with this psychological burden, Dowell prefers to dissociate from the reality of betrayal, which seems to help him live happily in the long run:

If for nine years I have possessed a goodly apple that is rotten at the core and discover its rottenness only in nine years and six months less four days, isn't it true to say that for nine years I possessed a goodly apple? (Ford, 1915/1990, p.11)

He believes that Edward, Leonora, and Florence "made [him] so happy that [he] doubt $[\mathrm{s}]$ if even paradise, that shall smooth out temporal wrongs, shall ever give [him] the like" (Ford, 1915/1990, p.81). Dowell's traumatic experience of being deceived is absent from his memory for nine years during which he is in a normal psychic state (Freud and Breuer, $1893 / 2001$, p.7). He represses the reality of adultery whereby he tolerates its incongruous effects. Dowell's reaction is a telling example of Caruth's formulation that, as a traumatised subject, he fails to witness the trauma of adultery as it happens and lives subconsciously as if it has never happened.

It is only when Dowell learns about Florence's betrayal for the second time that his trauma is actualized, which can be formulated as Nachträglichkeit in Freudian terms. Dowell is aware of the fact that Florence has been deceiving him for a long time - he is even warned by Leonora - but prefers to remain ignorant. When an Englishman called Bagshawe uncovers the truth about Florence and Jimmy, however, his trauma of betrayal is reactivated after a period of latency. While talking with Bagshawe, Dowell sees Florence running in the street with a white face and rushing in at the swing doors. Florence escapes them because Bagshawe knows her affair with Jimmy, as we learn from Bagshawe himself: "The last time I saw that girl she was coming out of the bedroom of a young man called Jimmy at five o'clock in the morning. In my house at Ledbury. You saw her recognize me" (Ford, 1915/1990, pp.118-119). Baffled by what he hears, Dowell cannot even move for a while and "a long time afterwards [he] pulled [himself] out of the lounge and went up to Florence's room" (Ford, 1915/1990, p.119). Dowell's pulling himself out suggests that he finds it difficult to react to Florence's betrayal of him. His numbness can be regarded as a reminiscent of a traumatised subject unable to react to a traumatic event.

Besides physical immobility, Dowell experiences traumatic retrograde amnesia after Florence's suicide. When he enters her room, it turns out to be too late for her to be saved by her husband; she has already committed suicide with a little flask of nitrate of amyl which Dowell finds necessary for her to cure her heart disease and therefore does not grasp at first what she has done. In the following three or four days, Dowell, "in a state just simply cataleptic", turns into a "walking dead" and only has "impressions" of her death which he pieces together afterwards (Ford, 1915/1990, p.129). It seems that he fails to grasp her suicide and only remembers seemingly unimportant details instead of her death: "[My] recollection of that night is only the sort of pinkish effulgence from the electric-lamps in the hotel lounge ... I pieced it together afterwards" (Ford, 1915/1990, pp.127-129). Onega argues that "the symptoms of trauma are manifested in total or partial amnesia, temporal disorientation, and the compulsion to repeat or 'act out' the traumatic event in the form of intrusive thoughts, hallucinatory images, or disturbing dreams" (2012, p.84). In The Good Soldier, Dowell develops partial amnesia of Florence's death and only has a few impressions of that night. Her death is ungraspable for Dowell and, therefore, he cannot fully understand and recall what has happened to her. 
Furthermore, Dowell undergoes affective numbing, which is also another symptom of trauma. Reconsidering the death of his wife, Dowell realizes that he felt like doing nothing about it:

And I thought nothing; absolutely nothing. I had no ideas; I had no strength. I felt no sorrow, no desire for action, no inclination to go upstairs and fall upon the body of my wife. I just saw the pink effulgence, the cane tables, the palms, the globular match-holders, the indented ash-trays. (Ford, 1915/1990, pp.128129).

Dowell dissociates from the reality surrounding him and has neither feelings nor ideas about her death. The only thing he feels is numbness:

I am unwilling to attribute my feelings at that time to anything so concrete as a shock. It was a feeling so tranquil. It was as if an immensely heavy — an unbearably heavy knapsack, supported upon my shoulders by straps, had fallen off and left my shoulders themselves that the straps had cut into, numb and without sensation of life. (Ford, 1915/1990, p.142).

Dowell's numbness remains until Leonora tells him that "it was stupid of Florence to commit suicide" (Ford, 1915/1990, p.125) which "was the first knowledge [Dowell] had that Florence had committed suicide. It had never entered [his] mind" (Ford, 1915/1990, p.126). Furthermore, when he learns from Leonora that Florence had an affair with Edward, Dowell is paralysed:

I didn't say anything and I don't suppose I felt anything ... No, I remember no emotion of any sort, but just the clear feeling that one has from time to time when one hears that some Mrs So-and-So is au mieux with a certain gentleman. (Ford, 1915/1990, p.124).

Unable to assimilate his traumatic experiences of betrayal and suicide, Dowell develops traumatic retrograde amnesia:

When for the purpose of these writings I have tried to figure her [Florence] out, I have thought about her as I might do about a problem in algebra. But it has always been as a matter for study, not for remembrance. She just went completely out of existence, like yesterday's paper. ... It simply didn't interest me. Florence didn't matter. (Ford, 1915/1990, pp.141-142)

When asked how it feels to be a deceived husband, Dowell feels nothing: "It feels just nothing at all. It is not Hell, certainly it is not necessarily Heaven. So I suppose it is the intermediate stage. What do they call it? Limbo. No, I feel nothing at all about that" (Ford, 1915/1990, p.82). In keeping with Caruth's suggestions above, Dowell seems to undergo affective numbing that has begun during his realization of betrayal. He avoids stimuli that would remind him of the event and remains numb and possessed by the traumatic memories of betrayal. At the same time, however, he is aware of the fact that he needs to deal with his limbo state. He knows that he needs to solve things out:

Do you understand the feeling - the sort of feeling that you must get certain matters out of the way, smooth out certain fairly negligible complications before you can go to a place that has, during all your life, been a sort of dream city? (Ford, 1915/1990, p.143).

With the purpose of overcoming his traumatic affects, Dowell starts to write them down, which is a perfect example of dealing with one's traumatic memories.

The ways of dealing with traumatic experiences have long been a matter of discussion among psychoanalysts and psychiatrists. One of the first methods proposed by Freud and Breuer is articulation. They argue that the traumatised subject needs to transfer his/her repressed traumatic memories from his/her unconsciousness to consciousness through articulation, which "serves as a substitute for action; by its help, an affect can be 'abreacted' almost as effectively" (1893/2001, p.8). Therefore, narrating traumatic memories seems to be an alternative way of dealing with one's traumatic affects. Otherwise, they underline the fact that "any recollection of the [traumatic] event retains its affective to begin with" $(1893 / 2001, p .8)$. The traumatised 
subject can only recover when s/he manages to abreact symptoms of trauma by remembering when the traumatic event occurred and describing that event thoroughly. In line with this, Pierre Janet also makes a distinction between traumatic and narrative memory. According to him, traumatic memory is "a fixed idea of a happening" (1919/1976, p.663) whereas narrative memory is an "action of telling a story" (1919/1976, p.661) which helps the traumatised subject to confer meaning onto traumatic memories. It is only through narrative memory that the fragmented traumatic memories can become a part of the traumatised subject's life.

In The Good Soldier, Dowell's efforts to narrate his traumatic memories best represent dealing with one's trauma through articulation. The novel is narrated by an unreliable narrator in the form of a first person narrator. Ansgar Nünning argues that "the real focus of the novel is not on the past events as such but on the narrator's [Dowell's] surmises about what has happened, on his ignorance and misapprehension" (2008, p.60). Likewise, Pericles Lewis states that "Ford tries to recreate Dowell's ignorance of his wife's adultery by representing events not in a casual sequence but as they occur to Dowell during the course of his reminiscences" (2007, p.159). As these descriptions suggest, both critics agree on the fact that the whole story is based on Dowell's unreliable memory. Although valid, the criticism on the use of the unreliable narrator has yet to consider Dowell's traumatic past which makes his narration unreliable.

What mainly triggers Dowell's unreliable narrative style is his attempts to deal with and move beyond his traumatic past. Accordingly, he feels compelled to transform them into a comprehensive narrative, a situation which he finds similar to that of the victims of a national disaster:

You may well ask why I write. And yet my reasons are quite many. For it is not unusual in human beings who have witnessed the sack of a city or the falling to pieces of a people to desire to set down what they have witnessed for the benefit of unknown heirs or of generations infinitely remote; or, if you please, just to get the sight out of their heads. (Ford, 1915/1990, p.9).

Dowell's desire to get his experiences out of his mind by putting them into words seems to resonate with that of traumatized subjects who try to cope with their traumatic experiences and/or memories. Onega argues that "the process of 'working through' of trauma requires the transformation of these fragmentary and painful 'mnemonic residues' into a temporally ordered and comprehensive narrative capable of conferring meaning onto the true nature of the events" (2012, p.84). Through narrative memory, then, the traumatic memory is transformed into a story, which helps the traumatized narrators or witnesses to deal with their traumatic affects. In line with this, Dowell narrates his traumatic memories to "a sympathetic soul" (Ford, 1915/1990, p.17). However, towards the end of the narration, he cannot solve anything in his mind. Instead, he is left with a chaotic state of mind: "I don't know. I know nothing. I am very tired" (Ford, 1915/1990, p.282). Therefore, it might be argued that Dowell is possessed by his traumatic memories even though he tries to overcome them through articulation.

In conclusion, this paper strongly demonstrates that John Dowell is a character traumatically affected by the collapse of his marriage, the accompanying adultery, and his wife's suicide. He remains confounded in the end; he comes to see that it is rather difficult to interpret what is going on around him. Before learning about the deception, the only thing that motivates him is not losing what the appearance of marriage brings him. He states that "Mind, I am not saying that this is not the most desirable type of life in the world; that it is not an almost unreasonably high standard" (Ford 1915/1990, p.44). However, his marriage no longer carries sacramental meanings for Dowell. Davida Pines states that "[i]n a traditional marriage plot, or courtship novel, marriage is the centre of a stable system of meaning" $(2003$, p. 74$)$, which is just the opposite in The Good Soldier because marriage does not have the connotations of stability but of confusions. Within the framework of trauma theory, John Dowell, unable to 
transform his traumatic experiences and memories into a temporally well-ordered and comprehensive narrative, is trapped within his traumatic past.

\section{References}

Bort, B. (1967). The Good Solder: Comedy or tragedy? Twentieth Century Literature. 12:4, 194-202.

Caruth, C. (1995). Introduction. In C. Caruth (Ed.), Trauma: Explorations in memory (pp.312). Baltimore: John Hopkins UP.

Charcot, J-M. (2014). Clinical lectures on diseases of the nervous system. London and New York: Routledge. (Original work published 1991)

Dreiser, T. (1997).The saddest story. In F. Macshane (Ed.), Ford Madox Ford: The critical heritage (pp.47-51). London: Routledge. (Original work published 1915)

Ford, M-F. (1990). The Good Soldier. Oxford: Oxford UP. (Original work published 1915)

Freud, S. (1939). Moses and monotheism. K. Jones (Trans.). London: Hogarth Press and the Institute of Psycho-Analysis.

(2001). Remembering, repeating and working through. In J. Strachey, A. Freud, A. Strachey \& A. Tyson (Eds. and Trans.), The standard edition of the complete psychological works of Sigmund Freud (1911-1913) (Vol.12) (pp.145-156). London: Vintage. (Original work published 1914)

(1950). Project for a scientific psychology. In James Strachey (Eds. and Trans.), The standard edition of the complete psychological works of Sigmund Freud (Vol. 1). (pp.281-391). London: Hogarth Press. (Original work published 1895)

Freud, S., \& Breuer, J. (2001). On the psychical mechanism of hysterical phenomena: Preliminary communication. In J. Strachey, A. Freud, A. Strachey \& A. Tyson (Eds. and Trans.), The standard edition of the complete psychological works of Sigmund Freud (1893-1895) (Vol.2). (pp.3-17). London: Vintage. (Original work published 1893)

Janet, P. (1976). Psychological healing: A historical and clinical study. E. Paul and C. Paul (Trans.). New York: Arno. (Original work published 1919)

Lewis, P. (2007). The Cambridge introduction to modernism. Cambridge, Cambridge University Press.

Leys, R. (2000). Trauma: A genealogy. Chicago: The University of Chicago Press.

Luckhurst, R. (2008). The trauma question. New York: Routledge.

Moran, P. (2007). Virginia Woolf, Jean Rhys, and the aesthetics of trauma. New York: Palgrave Macmillan.

Nünning. A. (2008). Reconceptualising the theory, history, and generic scope of unreliable narration: Towards a synthesis of cognitive and rhetorical approaches. In E. D'hoker and G. Martens (Eds.), Narrative unreliability in the twentieth-century first-person novel (pp.29-76). Berlin: Walter de Gruyter.

Onega, S. (2012). Affective knowledge, self-awareness and the function of myth in the representation and transmission of trauma: The case of Eva Figes' Konek Landing. Journal of Literary Theory 6.1, 83-101.

Onega, S., \& Ganteau, J-M. (2011). Introduction. In S. Onega and J.M. Ganteau (Eds.), Ethics and trauma in contemporary British fiction (pp.7-19). Amsterdam: Rodopi.

Pines, D. (2003). Irony and the marriage plot in The Good Soldier. In R. Hampson and M. Saunders (Eds.), Ford Madox Ford's modernity (pp.73-82). Amsterdam: Rodopi.

Robertson, R-M. (1993). The wrong 'saddest story': Reading the appearance of postmodernity in Ford's Good Soldier. In B. Readings \& B. Schaber (Eds.), Postmodernism across the ages (pp.171-187). New York: Syracuse University Press. 
West, R. (1997). Mr. Hueffer's new novel. In F. Macshane (Ed.), Ford Madox Ford: The critical heritage (pp.44-46). London and New York: Routledge. (Original work published 1915)

Y1lmaz, H. (2017). The phenomenology of the self and others in Virginia Woolf's The Waves, Joseph Conrad's Lord Jim, and Ford Madox Ford's The Good Soldier. Unpublished PhD. Diss., Hacettepe University, Ankara, Turkey. 